\title{
Improvement of plant growth and seed yield in Jatropha curcas by a novel nitrogen-fixing root associated Enterobacter species
}

\author{
Munusamy Madhaiyan ${ }^{1}, \mathrm{Ni}$ Peng ${ }^{1}$, Ngoh Si Te${ }^{1}$, Cheng Hsin I', Cai Lin ${ }^{1}$, Fu Lin ${ }^{1}$, Chalapathy Reddy²,
} Hong Yan $^{2}$ and Lianghui $\mathrm{Ji}^{1^{*}}$

\begin{abstract}
Background: Jatropha curcas L. is an oil seed producing non-leguminous tropical shrub that has good potential to be a fuel plant that can be cultivated on marginal land. Due to the low nutrient content of the targeted plantation area, the requirement for fertilizer is expected to be higher than other plants. This factor severely affects the commercial viability of J. curcas.

Results: We explored the feasibility to use endophytic nitrogen-fixing bacteria that are native to J. curcas to improve plant growth, biomass and seed productivity. We demonstrated that a novel N-fixing endophyte, Enterobacter sp. R4-368, was able to colonize in root and stem tissues and significantly promoted early plant growth and seed productivity of $\mathrm{J}$. curcas in sterilized and non-sterilized soil. Inoculation of young seedling led to an approximately $57.2 \%$ increase in seedling vigour over a six week period. At 90 days after planting, inoculated plants showed an average increase of 25.3\%, 77.7\%, 27.5\%, 45.8\% in plant height, leaf number, chlorophyll content and stem volume, respectively. Notably, inoculation of the strain led to a $49.0 \%$ increase in the average seed number per plant and 20\% increase in the average single seed weight when plants were maintained for 1.5 years in nonsterilized soil in pots in the open air. Enterobacter sp. R4-368 cells were able to colonize root tissues and moved systemically to stem tissues. However, no bacteria were found in leaves. Promotion of plant growth and leaf nitrogen content by the strain was partially lost in nifH, nifD, nifK knockout mutants, suggesting the presence of other growth promoting factors that are associated with this bacterium strain.
\end{abstract}

Conclusion: Our results showed that Enterobacter sp. R4-368 significantly promoted growth and seed yield of $J$. curcas. The application of the strains is likely to significantly improve the commercial viability of $J$. curcas due to the reduced fertilizer cost and improved oil yield.

Keywords: Bacterial endophytes, Nitrogen fixation, Enterobacter, Plant growth promotion, Jatropha curcas L, Biofuel

\section{Background}

The rapid rise of fossil fuel price, diminishing global fuel reserve and the concerns about global warming, resulted from the accumulation of atmospheric Greenhouse Gases, have served as the three catalysts in the recent biofuel boom [1]. The environmental benefit of biofuel consumption is attributed from the widely believed outcome of reduced $\mathrm{CO}_{2}$ emission. Recently, a new issue

\footnotetext{
* Correspondence: jilh@tll.org.sg

'Biomaterials and Biocatalysts Group, Temasek Life Sciences Laboratory, 1 Research Link, National University of Singapore, Singapore 117604, Republic of Singapore

Full list of author information is available at the end of the article
}

has been brought up for debate regarding the benefit of biofuels. Nitrous oxide $\left(\mathrm{N}_{2} \mathrm{O}\right)$ is produced naturally in the soil during the microbial processes of nitrification and denitrification. A significant percentage of the nitrogen fertilizer used in biofuel production is converted to reactive nitrogen $\mathrm{N}_{2} \mathrm{O}$, a greenhouse gas which has 310 times the ability of $\mathrm{CO}_{2}$ to trap heat in the atmosphere [2]. The benefit of $\mathrm{CO}_{2}$ mitigation through biofuel consumption will be diminished if the use of nitrogen fertilizer is not controlled [3-5].

Jatropha curcas (Jatropha) is a small woody plant belonging to the Euphorbiaceae family. Several unique

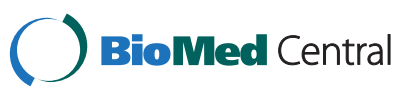


characteristics of Jatropha make it an ideal plant for biodiesel production [6-8]. These include the ability to grow on marginal land, low requirement for water, a non-food crop status and fast oil production in 0.5-2 years after planting compared to more than 3 years for oil palm. Accordingly, several Asian countries, particularly Indonesia and India, have made ambitious plans to promote Jatropha plantation. Apart from breeding programs for high yielding Jatropha varieties [9-11], agronomical practices, such as the application of inorganic fertilizer [12] and plant growth regulators, have also been reported to improve seed yield [13,14]. Application of nitrogen fertilizer has become an essential practice in modern agriculture, as it is vital to maintain competitive crop productivity. It is well known that legumes require much less input of nitrogen fertilizer owing to their natural capability to fix atmospheric nitrogen. This is attributed to nitrogenfixing rhizobia (diazotrophs), mostly belonging to species in the Rhizobium, Sinorhizobium, Mesorhizobium and Bradyrhizobium genera [15-18], forming a mutually beneficial symbiotic relationship with the bacteria supplying nitrogen source to the plants while drawing carbon source from the plants cells [19-21]. The formation of symbiotic nitrogen-fixing nodules involves complex genetic and chemical interactions between the diazotroph and the host. For example, the symbiosis between Sinorhizobium meliloti and its plant hosts begins when the plant secretes an array of betaines and flavonoids into the rhizosphere. These compounds attract S. meliloti to the surface of the root hairs of the plant where the bacteria begin secreting nodulation factor [22,23]. As a consequence, symbiotic nodule-forming nitrogen fixation is found almost exclusively in legume species [24].

Interestingly, an increasingly number of diazotrophic species, e.g., Azospirillum, Herbaspirillum, Burkholderia, Gluconacetobacter, have been reported to form atypical symbiotic relationship with plants [25-27]. They often grow on the surface of the root system (rhizobacteria) although some are able to infect plant tissues (endophytic bacteria) and perform nitrogen fixation, which in turn promotes plant growth [28]. Perhaps, the best examples of endophytic nitrogen-fixation can be found in sugarcane and wild rice, with Herbaspirillum, Gluconacetobacter, Enterobacter, Azospirillum, Swaminathania and Acetobacter being the major contributors of nitrogen-fixing species [27,29-32]. Photosynthetic Bradyrhizobia are the natural endophytes of the African wild rice Oryza breviligulata while the intercellular colonization and growth-promoting effects of a Methylobacterium species was observed in common rice although the latter was believed to result from phytohormone secretion by the bacterium $[33,34]$.

As Jatropha is targeted to be grown in marginal land where soil nutrient is low, the requirement for nitrogen fertilizer will be higher than other crops. Therefore, any technology that reduces nitrogen fertilizer usage will be highly desirable [6-8]. To date, there is little research on naturally occurring diazotrophs in neither this plant nor the application of these microbes for improvement of plant productivity. Here we present our investigation on the isolation, characterization and application of root associated nitrogen-fixing bacteria from Jatropha cultivars.

\section{Results}

Isolation and characterization endophytic nitrogen-fixing bacteria from Jatropha

Endophytic nitrogen (N)-fixing bacteria were isolated from tissues of three germplasm accessions of Jatropha based on their ability to grow in nitrogen-free medium. Analysis of $16 \mathrm{~S}$ rRNA sequences of candidate strains isolated revealed that 54 of them were closely related to known species in the Enterobacter genus. Six strains are clustered with the known species, such as Enterobacter radicincitans $\mathrm{D} 5-23^{\mathrm{T}}$ and Enterobacter oryzae Ola51 ${ }^{\mathrm{T}}$, whereas the other 10 strains formed a distinct new cluster, which are characterized in detail in this report (Figure 1). After confirmation of the presence of nifH genes by PCR and DNA sequencing, we selected a few Enterobacter strains and examined their ability to fix atmospheric nitrogen under in vitro and in planta conditions by acetylene reduction (AR) assay (nitrogenase assay). The Enterobacter strains that showed high AR activity in vitro were selected for the assessment of nitrogenase activity in planta by inoculation to Jatropha seedlings. The AR-activity in vitro varied widely among the strains, ranged from 12.4 to $1060.7 \mathrm{nmol} \mathrm{C}_{2} \mathrm{H}_{4} \mathrm{mg}$ protein $^{-1} \mathrm{~h}^{-1}$ while the in planta AR activity ranged from 43.7 to $186.3 \mathrm{nmol} \mathrm{C}_{2} \mathrm{H}_{4}$ plant $^{-1} \mathrm{~h}^{-1}$ (Figure 2). One of the strains, R4-368 showed the best AR activity, and was thus selected for further studies.

\section{Inoculation of Enterobacter sp. strain R4-368 improved production of biomass and seeds}

To confirm that Enterobacter sp. R4-368 was able to improve agronomic traits of Jatropha plant, its seedlings were inoculated with the strains by seed soaking. As expected, at 45 days after sowings [35], the inoculated plants accumulated $30.51 \%$ higher dry biomass associated with significantly increased leaf chlorophyll content and growth vigour than the non-inoculated control plants (Table 1). To further establish the growthpromoting effect of R4-368, Jatropha plants were inoculated with the strain in the root system by watering a bacterium suspension into the soil that had been sterilized before planting. These plants were maintained in the open air. Again, R4-368 treated plants showed significant improvements in plant height, leaf counts or plant canopy and leaf chlorophyll content compared with the untreated control plants (Figure 3). At 120 


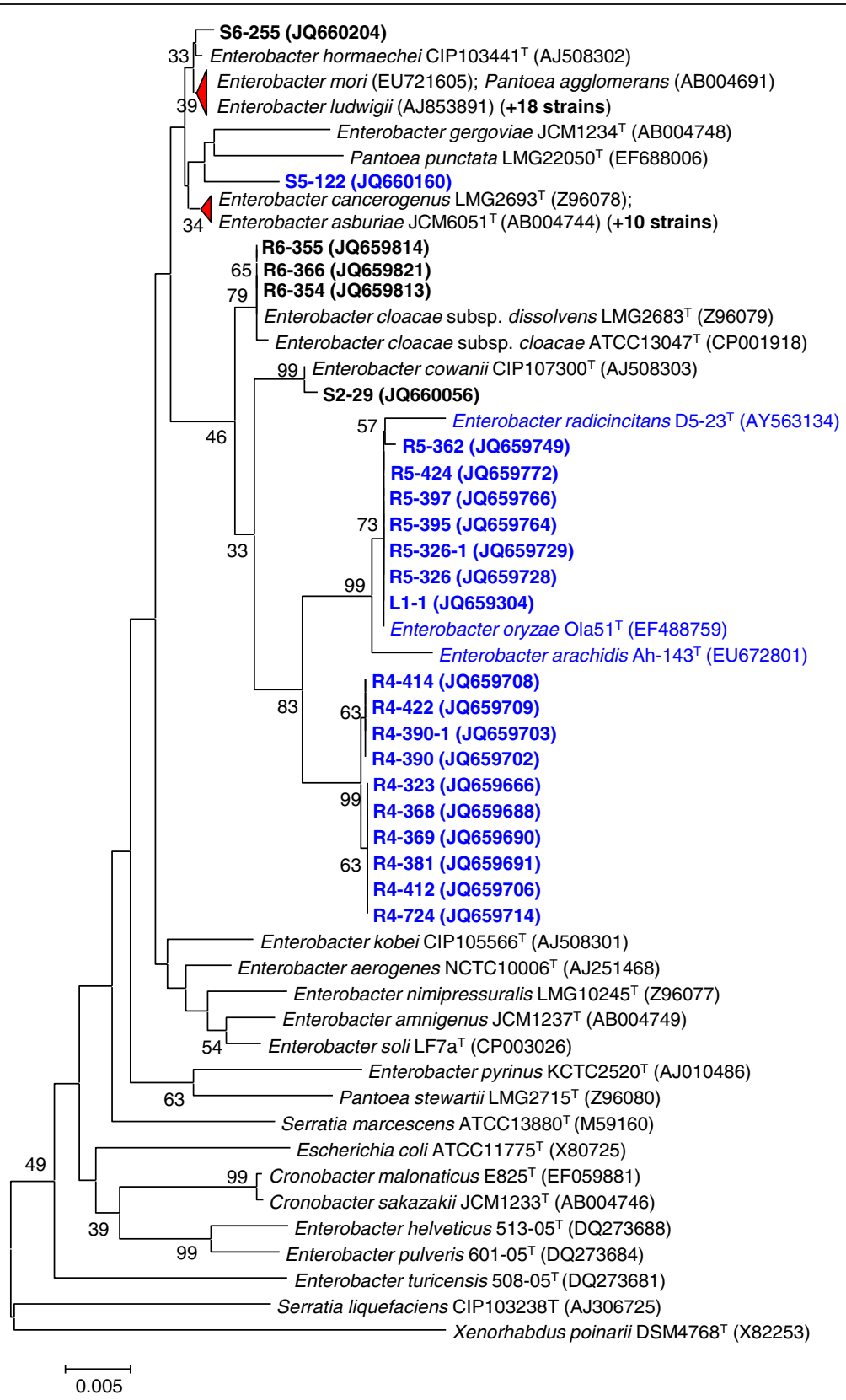

Figure 1 Taxonomical classification of isolated Enterobacter strains. Phylogenetic tree was based on 165 rRNA gene sequences, of which the Genebank accession numbers are shown in the brackets. Bootstrap values (expressed as percentages of 1000 replications) greater than $30 \%$ are shown at the branch points. Bar: 0.005 substitutions per nucleotide position. Potential nitrogen-fixing strains, which were positive for the nifH gene as judged by PCR amplifications and sequence confirmation, are shown in indicated in blue. The number of isolates highly related to $E$. ludwigii and E. asburiae are indicated by the number in the bracket, respectively.

DAI, treated plants recorded an increase of $18.3 \%$, $50.3 \%, 11.4 \%$ and $69.5 \%$ over the control mockinoculated plants in plant height, leaf counts, leaf chlorophyll content and stem volume respectively (Figure 3A-D). To evaluate the effects of bacterial inoculation on seed production, plants were grown in sterilized and nonsterilized soil in large pots and maintained in the open air. Notably, the average seed set number per tree was increased by approximately $177 \%$ at the end of the observation period when sterilized soil was used. The increase was reduced to approximately $49.0 \%$ when non-sterilized soil was used (Figure 4C). Student's t-test showed that the treated populations produced significantly more seed sets than non-treated ones in both experiments $(\mathrm{p}<0.05)$. The average seed weight was increased approximately $10 \%$ in Trial I and $20 \%$ in Trial II, both increases being very 


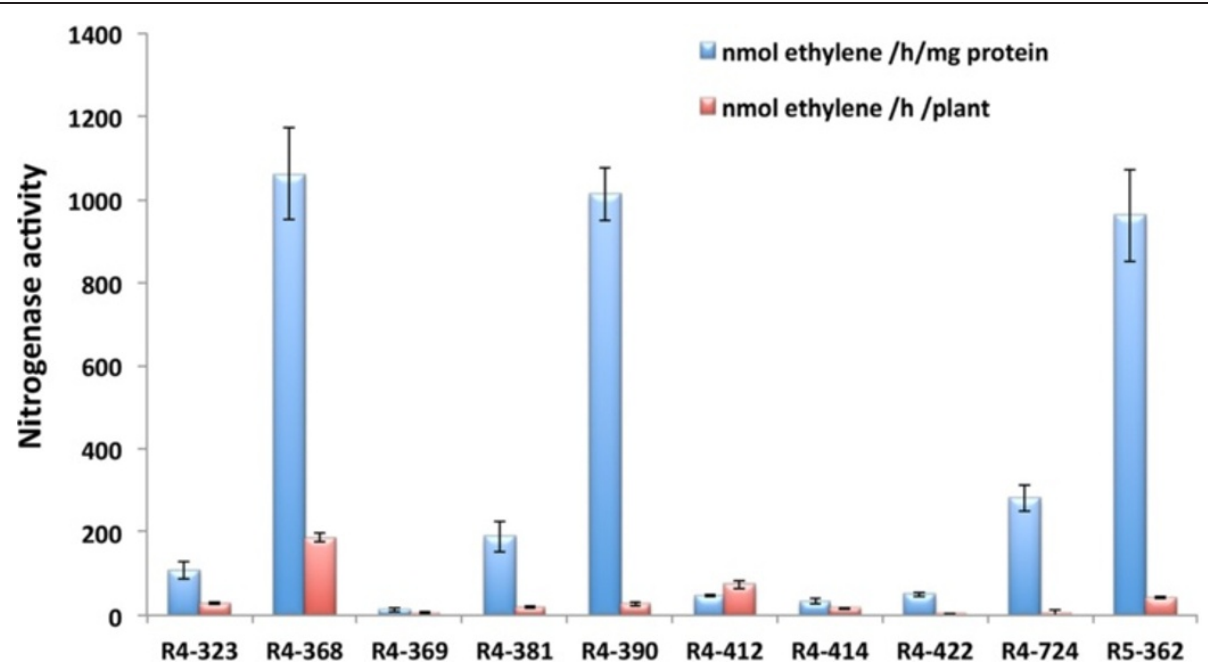

Figure 2 Nitrogenase activities of selected isolates from Jatropha cultivars. Acetylene reduction (AR) activity was measured in vitro (pure cultures) and in planta conditions. Error bars represent SD $(n=4)$.

significant according to Student's t-test of individual seed weight $(\mathrm{p}<0.01)$. The seed set improvement was mainly attributed to an increase of female-male flower ratio, which led to a corresponding increase of fruit and seed sets. There appeared to have a slight increase ( 15.2\%) of total flower numbers (Additional file 1: Table S1).

\section{Characterization of the R4-368 nitrogen-fixation genes}

A shot-gun sequencing using the 454 sequencing method yielded 76 contigs which are more than $0.5 \mathrm{~kb}$ in size. Blast search of the contigs against the nucleotide and microbial genome databases at the NCBI revealed a region of approximately $23 \mathrm{~kb}$ which shows high homology to the nif operons (GenBank: $\times 13303.1)$ of Klebsiella pneumonia, one of the best characterized plant root-associated nitrogen fixing bacteria [37,38]. Examination of the annotations, which was done by the RAST (Rapid Annotation using Subsystem Technology) automated annotation service [39], confirmed the presence of a complete nif gene cluster with identical organization to those found in K. pneumonia (Figure 5A). Alignment of the two nif gene clusters revealed an overall sequence identity of $92.5 \%$ at the DNA level. The 20 predicted proteins share between $51.7 \%$ and $95.6 \%$ identity with highly similar protein sizes. NifH is the most conserved protein with $95.6 \%$ amino acid identity between the two species (Figure 5B). The sequence of Enterobacter sp. R4-368 nif operon is deposited to Genbank accession no. KC989924.

\section{Growth promoting activity of R4-368 is partially attributed to nitrogen-fixation}

To elucidate the mechanism of plant growth promotion by Enterobacter sp. R4-368, knockout mutants were created for nifH, nifD and nifK gene individually. The success of gene deletion was confirmed by Southern hybridization (Additional file 2: Figure S1). As expected the $\Delta$ nif mutants were completely devoid of nitrogenase activity in $\mathrm{N}$-free media. There is no significant variation in the endoglucanase activity or in the colony morphology in the $\Delta$ nif mutants. The knockout mutants were able to colonize Jatropha as judged by the high counts of endophytic bacteria population. At 45 DAI, the Wt R4368 -inoculated plants showed an increase of $90 \%, 64 \%$,

Table 1 Effects of R4-368 inoculation on the early growth parameters of Jatropha

\begin{tabular}{llllll}
\hline Treatments $^{\mathbf{a}}$ & Relative chlorophyll content & Nitrogenase activity & SVI $^{\mathbf{c}}$ & RG $^{\mathbf{d}}$ & Biomass $^{\mathbf{e}}$ \\
\hline Control & $34.91 \pm 3.91$ & $2.15 \pm 0.25$ & $2024.2 \pm 33.7$ & $23.50 \pm 2.50$ & $117.9 \pm 3.67$ \\
R4-368 & $36.13 \pm 3.13$ & $8.70 \pm 0.25$ & $3182.0 \pm 170.5$ & $25.76 \pm 2.76$ & $153.9 \pm 5.83$ \\
LSD $(P \leq 0.05)$ & 1.94 & 1.24 & 134.2 & 0.65 & 14.2 \\
\hline
\end{tabular}

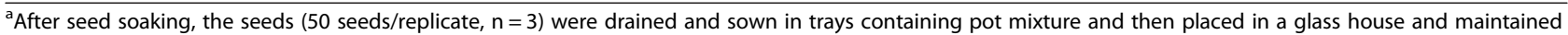
at $28^{\circ} \mathrm{C}$.

${ }^{b}$ Value expressed in $\mathrm{nmol} \mathrm{C}_{2} \mathrm{H}_{4}$ day $^{-1}$ seedlings ${ }^{-1}$. Each value represents mean \pm standard deviation (SD) of three replicates per treatment.

'Seedling vigour index [36] was calculated using the formula: SVI $=\%$ germination $\times$ seedling length (shoot length + root length) in $\mathrm{cm}$.

${ }^{d}$ Rate of germination (RG) was calculated using the following formula, $R G=\Sigma \mathrm{Ni} / \mathrm{Di}$ where $\mathrm{Ni}$ is the number of germinated seeds in a given time, and Di is the time unit (day).

${ }^{e}$ Each value represents mean of three replicates and expressed in grams. Samples were measured at 45 DAS. 


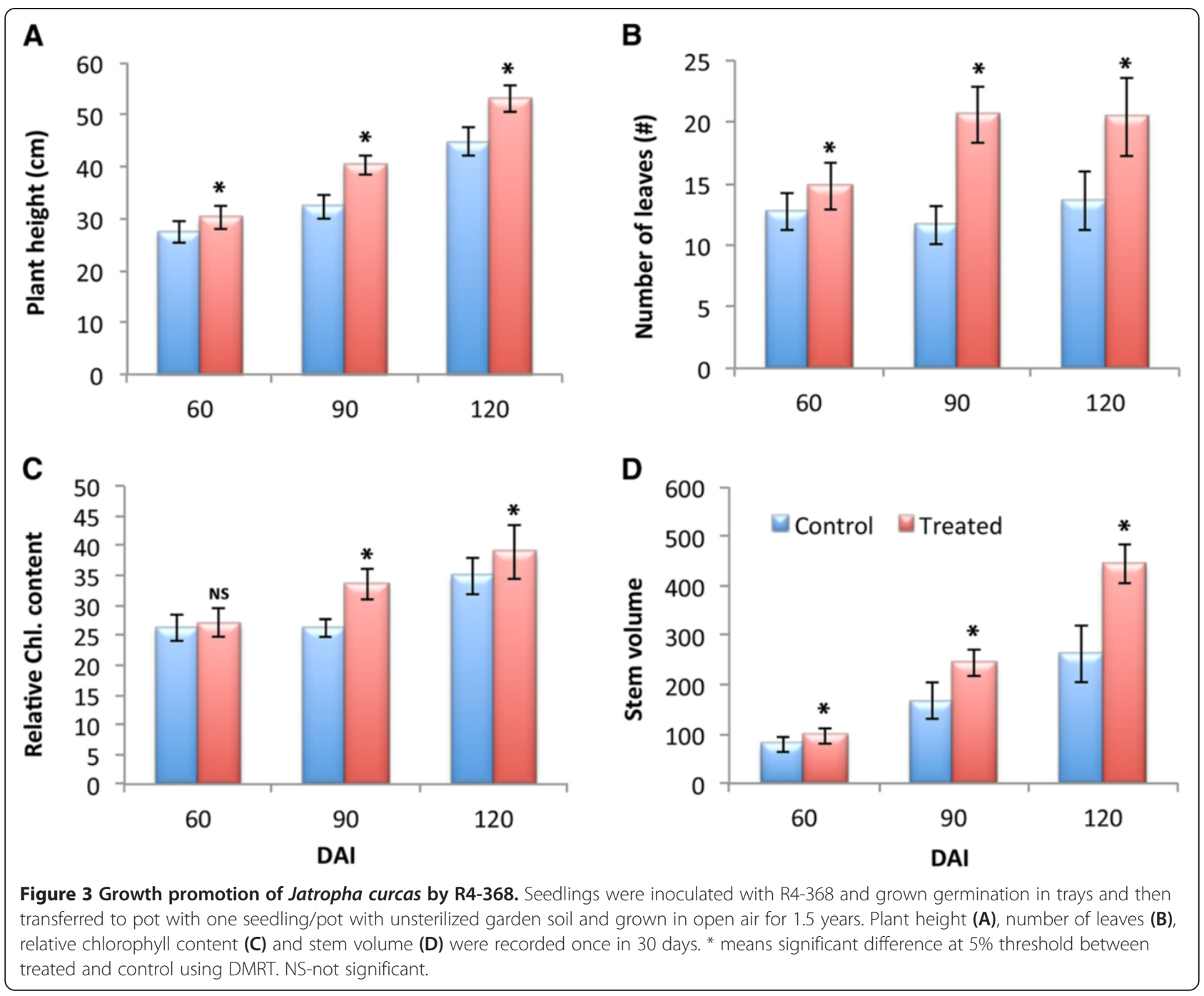

$173 \%$ and $133 \%$ in plant height, leaf number, shoot biomass and root biomass over the mock-inoculated plants, respectively. Interestingly, nifH, nifD and nifK knockout strains retained substantial growth promoting activity. Consistent with the function of nif genes, the leaf nitrogen content of $\Delta$ nifH, $\Delta$ nifD and $\Delta$ nifK inoculated plants were essentially the same as the control whereas it was increased by $118.9 \%$ in Wt R4-368-inoculated plants under $\mathrm{N}$-limiting conditions (Table 2). Jatropha seedlings inoculated with Wt and $\Delta$ nif mutants with $2 \mathrm{mM}$ ammonium sulphate significantly increased plant growth parameters, relative chlorophyll content, in planta AR-activity and partially recovered $\mathrm{N}$-deficiency in the $\Delta$ nifH, $\Delta$ nifD and $\Delta$ iffK inoculated plants (data not shown).

\section{Colonization of Enterobacter sp. R4-368 in Jatropha}

In order to study the interaction between Enterobacter sp. R4-368 and Jatropha at the molecular level, gene transformation and expression systems were developed.
Screening of several $E$. coli vectors available in the laboratory for their ability to transform Enterobacter sp. R4-368 using the electroporation method identified a highly competent vector, pMC1-EPS-RtGFP (Genbank accession no. KC989925). This vector contains the ColE1 origin of replication of pMK (MrGene, USA), a modified chloramphenicol resistance gene composed of the E. coli/bacteriophage T4 tac promoter. This drives the expression of catII gene derived from pUTmini-Tn5 CM [40], and a modified eGFP sequence, RtGFP [41] that is driven by the eps gene promoter of Enterobacter sp. R4-368.

To monitor the colonization of Enterobacter sp. R4-368 in Jatropha root system, both wild-type and nif knockout mutants were transformed with pMC1-EPS-RtGFP, which showed no discernible effect on growth and nitrogenase activity (data not shown). In gnotobiotic assay, GFP tagged cells of both wild-type and $\Delta$ nifH mutant were observed primarily on the surface and intercellular space of the root 

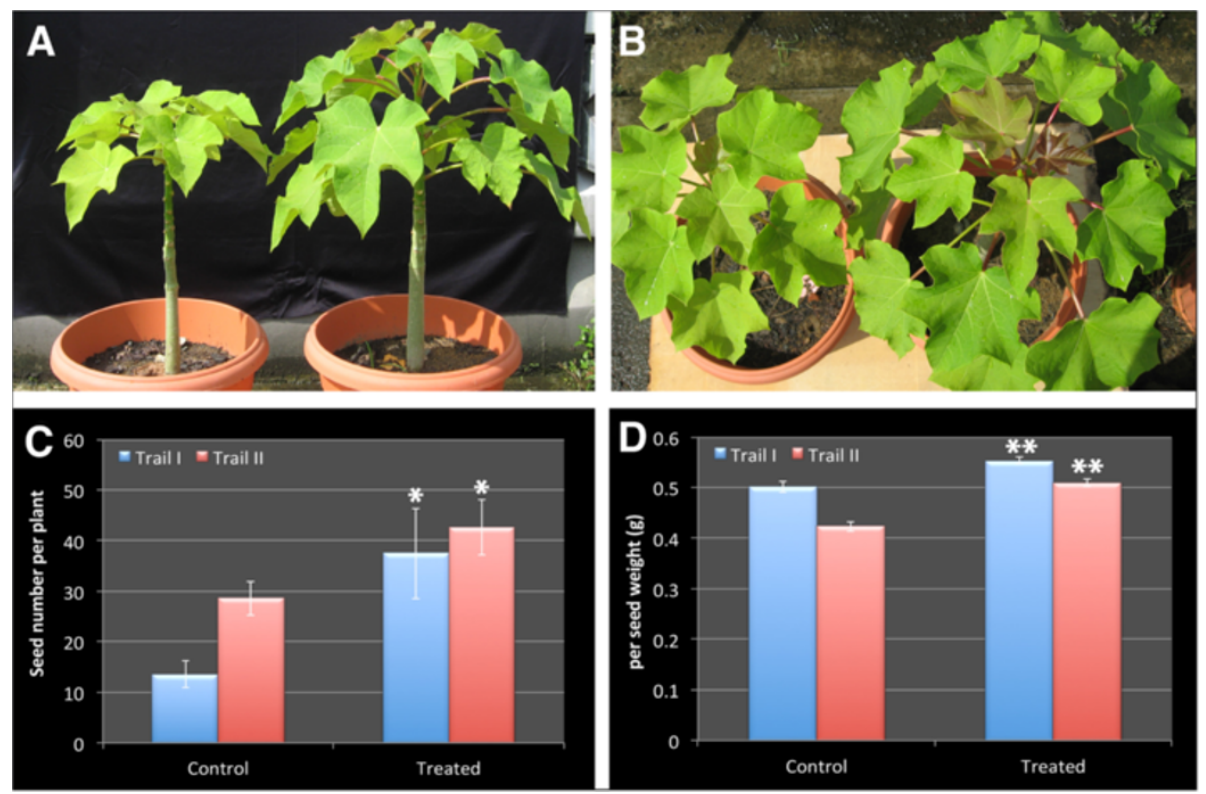

Figure 4 Effect of Enterobacter R4-368 inoculation on seed production. Plants were planted in pots in sterilized soil (compost/sand mix at 1:1 ratio and in $\$ 23 \mathrm{~cm}, 18 \mathrm{~cm}$ height pots; named as Trial I) or none-sterilized soil (nutrient poor clay soil in $\phi 30 \mathrm{~cm}, 28 \mathrm{~cm}$ height pots; named as Trial II). Trial I and Trial II were maintained in different locations and started in different seasons. R4-368 cell suspension (1.2 OD $600 \mathrm{~nm}, 50 \mathrm{ml} / \mathrm{pot})$ was applied to the plant root system at 21 days after seed germination. Fertiliser was applied regularly at about half of the recommended dose of approximately 50:30:30 g/plant/year. (A) Plant height (B) leaf canopy. Seed set numbers per plant (C) ( $\mathrm{n}=8$ in Trial I and $\mathrm{n}=12$ in Trial II) were measured at 480 and 520 DAI in Trail I and Trail II respectively and single seed weight (D) was calculated based the average of 180 randomly selected seeds per treatment except the non-treated for Trial I where only 117 seeds were measured. Error bars indicate standard error. * and ** indicate statistically significant between the treated and non-treated populations ( ${ }^{*} \mathrm{P}<0.05$ for seed set per plant and ${ }^{* *} \mathrm{P}<0.01$ for single seed weight) by Student's t-test.

tissues (Figure 6A-D). Typically microcolonies were formed on root hairs at 7 DAI and the presence of GFP in intercellular space of the root cortex was observed after 20 DAI (Figure 6D). Similar phenotypes were observed with $\Delta$ nifD mutants (not shown). Quantification of endophytic bacterial population density in the tissues at 45 DAI revealed small difference between the Wt and $\Delta$ nif mutants. Both strains were also recovered from stem tissues, indicating that they were able to move systemically from root to the upper parts of plants. However, bacteria were not detected in leaf tissues at $45 \mathrm{DAI}$, suggesting that R4-368 primarily colonized root and stem tissues in jatropha (Table 3).

\section{Discussion}

Certain definitive evidence that a particular bacterium provides fixed nitrogen to the plant should be provided according to Iniguez et al. [35]. One of the critical evidence is that the bacterial inoculation should increase the nitrogen concentration of plants and relieve the nitrogen deficiency symptoms under nitrogen-limiting conditions. These effects should not be present while using nif mutant or uninoculated controls [35]. We tried to illustrate this by inoculating with the wild-type and $\Delta$ nif mutants of our strain in pot cultures under nitrogen-limiting conditions.
Besides improving the plant growth and biomass of Jatropha, the wild-type strain significantly increased the content of nitrogen and chlorophyll content of the leaves whereas plants inoculated with $\Delta$ nif mutants showed reduced growth and chlorotic leaves, similar to the noninoculated control (Table 1 and Table 2).

Increasing reports of natural endophytic bacteria with plant growth promotion (PGP) traits have been reported. Besides nitrogen-fixation, PGP bacteria may modulate plant shoot and root development by secretion of plant hormones or enzymes; such as auxin and 1-aminocyclopropane-1-carboxylate deaminase that reduces ethylene level in plant tissues; enhancement of resistance to pathogens through releasing volatile compounds; solubilisation of soil phosphorus and trace elements $[19,21,43]$. To date, a small number of endogenous bacteria species have been isolated from J. curcas, including Pseudonocardia sichuanensis [44], Nocardia endophytica [45], Pleomorphomonas diazotrophica [46], Aureimonas jatrophae and Aureimonas phyllosphaerae [47], Jatrophihabitans endophyticus [48] and Enterobacter cancerogenus [49]. However, none has been studied on the mechanistic aspects of plant growth promotion in this promising biofuel plant.

In this study, we surveyed the microbial diversity of Jatropha that were cultivated in the tropical region 


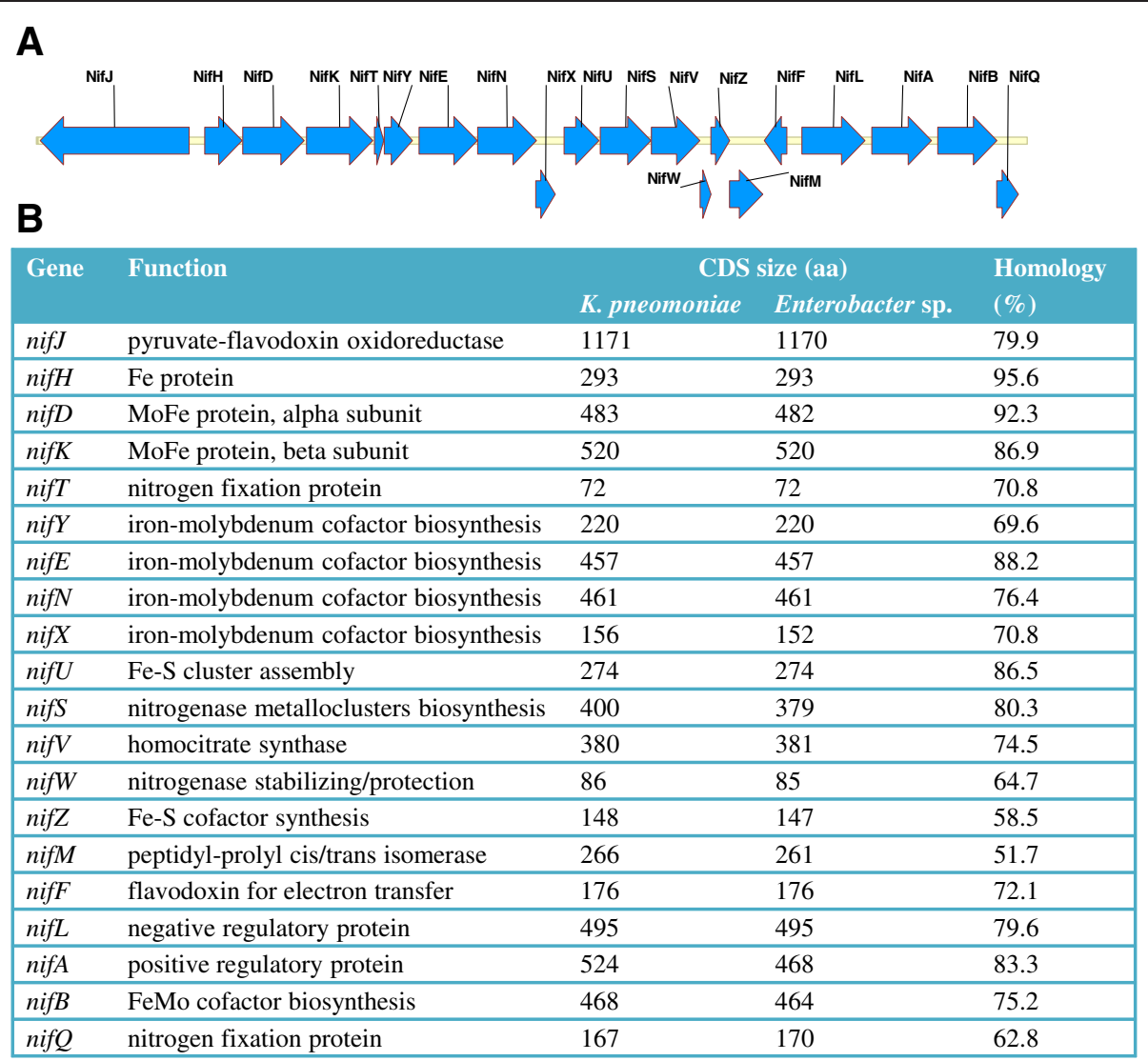

Figure 5 nif gene operon in Enterobacter sp. R4-368. (A) Organization of nif gene cluster. The coding DNA sequence (CDS) was predicted with RAST [39] and the CDS diagram was generated with Vector NTI v10. (B) Comparison of nif genes between Enterabacter sp. R4-368 and K. pneumonia (GenBank: ×13303.1).

(Singapore) and focused on the Enterobacter species that are native to Jatropha. Although a species identified as closely related to E. cancerogenus was reported to improve early growth parameters [49], our isolates appeared to be phylogenetically distinct as one group, represented by strains R4-368, shares 98.0\% 16S rDNA sequence identity to E. cancerogenus; while the second group containing 7 isolates share $97.7-97.8 \% 16 \mathrm{~S}$ rDNA sequence identity to that of E. cancerogenus (Figure 1).
The isolates in second group are more closely related to $E$. radicincitans $\mathrm{D} 5-23^{\mathrm{T}}$, E. oryzae Ola51 ${ }^{\mathrm{T}}$ and Enterobacter arachidis Ah- $143^{\mathrm{T}}$, which are known PGP bacteria in other crops [50-52].

From the agronomical point of view, Enterobacter sp. R4-368 is a promising biofertilizer strain. Apart from the confirmation of early growth parameters (Figures $3 \& 4$, Table $1 \&$ Table 2), which are similar to other findings with a related strain, E. cancerogenus [49], we have

Table 2 Effect of nitrogen fixation genes on growth promotion activity of R4-368 under N-limiting conditions

\begin{tabular}{|c|c|c|c|c|c|c|c|}
\hline Treatments $^{1}$ & $\begin{array}{l}\text { Plant height } \\
(\mathrm{cm})^{*}\end{array}$ & $\begin{array}{l}\text { Number of } \\
\text { leaves* }\end{array}$ & $\begin{array}{l}\text { Shoot } \\
\text { biomass (g)* }\end{array}$ & $\begin{array}{l}\text { Root } \\
\text { biomass (g)* }\end{array}$ & $\begin{array}{l}\text { Leaf } \mathrm{N} \\
\text { content (\%) }\end{array}$ & $\begin{array}{l}\text { N-fixing population } \\
(\log \mathrm{CFU} / \mathrm{g})^{5}\end{array}$ & $\begin{array}{l}\text { In planta AR activity } \\
\left(\mathrm{nmol} \mathrm{C}_{2} \mathrm{H}_{4} / \mathrm{h} / \mathrm{g}\right)^{5}\end{array}$ \\
\hline Wild type & $34.0 \pm 5.8$ & $10.0 \pm 2.4$ & $7.1 \pm 0.7$ & $1.4 \pm 0.1$ & $1.97 \pm 0.32$ & $7.47 \pm 0.05$ & $49.94 \pm 3.18$ \\
\hline$\Delta n i f H$ & $25.3 \pm 4.5^{b}$ & $8.1 \pm 1.2$ & $4.1 \pm 1.3^{b}$ & $0.7 \pm 0.1$ & $1.06 \pm 0.01$ & $5.86 \pm 0.10^{b}$ & $4.52 \pm 2.46^{b}$ \\
\hline$\Delta n i f D$ & $23.1 \pm 4.5^{b}$ & $7.1 \pm 1.2^{b}$ & $4.4 \pm 0.4^{b}$ & $0.6 \pm 0.1^{b}$ & $0.88 \pm 0.02^{b}$ & $5.78 \pm 0.21^{b}$ & $10.47 \pm 5.20^{b}$ \\
\hline$\Delta$ nifk & $22.6 \pm 3.9^{b}$ & $7.3 \pm 1.3^{b}$ & $4.4 \pm 0.5^{b}$ & $0.8 \pm 0.1$ & $1.26 \pm 0.03$ & $5.69 \pm 0.14^{b}$ & $8.12 \pm 2.55^{b}$ \\
\hline Mock & $17.9 \pm 1.3$ & $6.1 \pm 1.2^{b}$ & $2.6 \pm 0.5$ & $0.6 \pm 0.0^{b}$ & $0.90 \pm 0.03^{b}$ & $5.79 \pm 0.15^{b}$ & $8.08 \pm 2.23^{b}$ \\
\hline
\end{tabular}

${ }^{1}$ Bacterial inoculants $(50 \mathrm{ml} / \mathrm{pot}$ ) were applied near the root regions after transplanting while the control plant was applied with sterile distilled water. Plants were grown in the open air in a greenhouse. Plants were watered as needed with a nutrient solution containing $5 \mu \mathrm{M} \mathrm{CaCl}_{2}, 1.25 \mu \mathrm{M} \mathrm{MgSO}, 5 \mu \mathrm{M} \mathrm{KCl}, 1 \mu \mathrm{M} \mathrm{KH_{2 }} \mathrm{PO}_{4}$, $0.162 \mu \mathrm{M} \mathrm{FeSO}_{4}, 2.91 \mathrm{nM} \mathrm{H}_{3} \mathrm{BO}_{3}, 1.14 \mathrm{nM} \mathrm{MnSO}_{4}, 0.76 \mathrm{nM} \mathrm{ZnSO}_{4}, 0.13 \mathrm{nM} \mathrm{NaMoO}_{4}, 0.14 \mathrm{nM} \mathrm{NiCl}_{2}, 0.013 \mathrm{nM} \mathrm{CoCl}_{2}$, and $0.19 \mathrm{nM} \mathrm{CuSO}$.

${ }^{\mathrm{b}}$ The treatments are not significantly different from each other at $5 \%$ threshold.

*, $\mathrm{n}=7 ; \#, \mathrm{n}=4$; and $\S, 45$ DAl. 

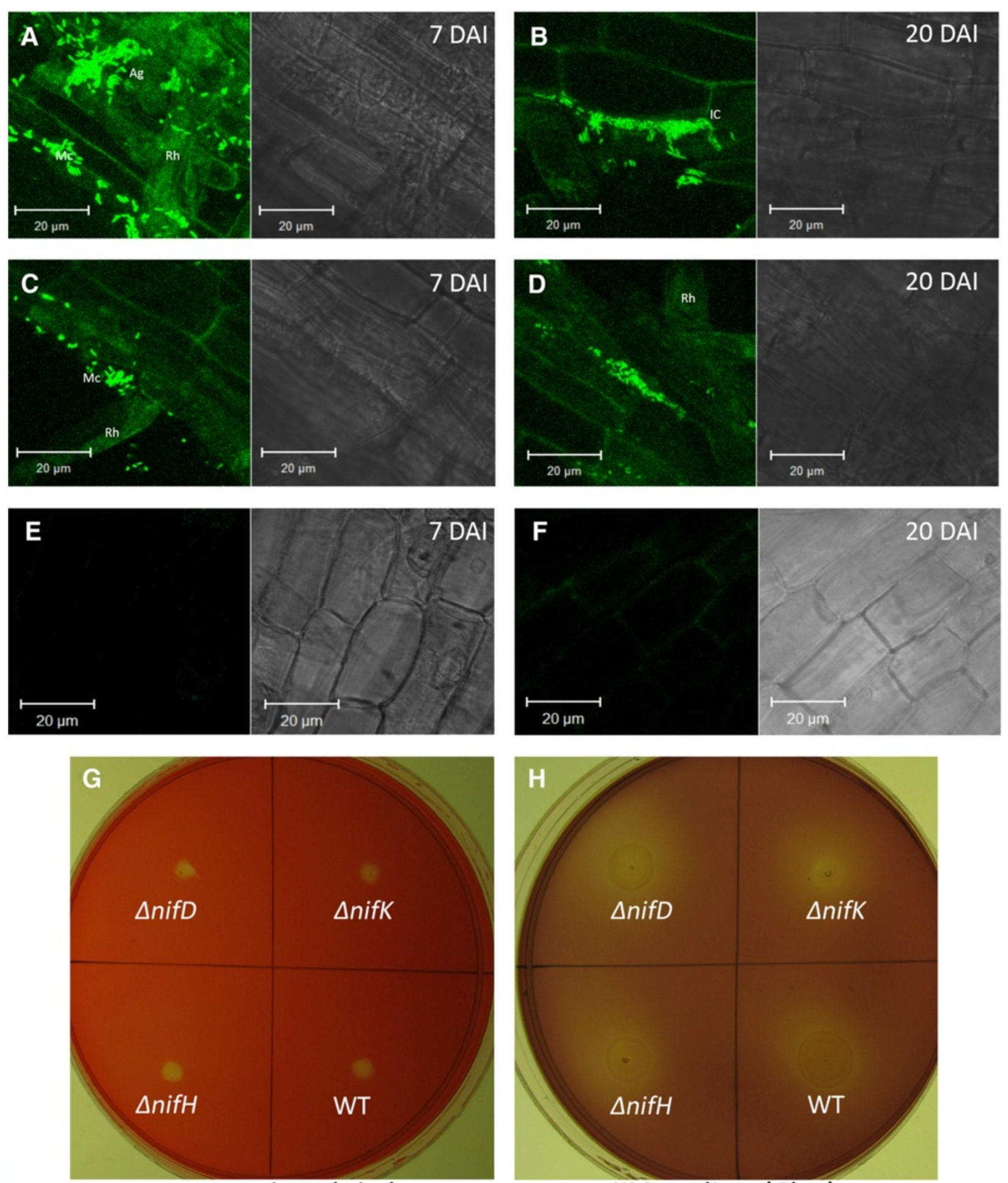

\section{KM medium (Glu-)}

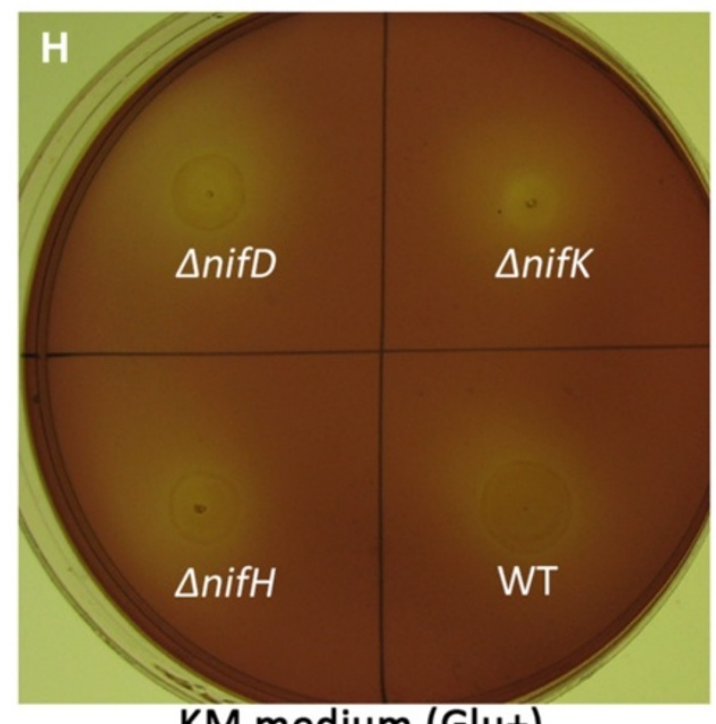

Figure 6 Plant Colonization and in vitro endoglucanase activity of Wt and $\Delta$ nifK mutants. (A) and (B): An optical section of root tissue infected of Wt R4-368 at 7 and 20 DAl respectively. (C) and (D): An optical section of root tissue infected of Wt R4-368 $\Delta$ nifH at 7 and 20 DAl respectively. (E) and (F) are the mock-inoculated control showing no GFP signal. Scale bars (bar, $20 \mu \mathrm{m})$ are shown in each image. Mc: microcolony; Rh: root hair; Ag: cell aggregates; IC: intercellular colonization. (G) and (H): Congo-red stained KM agar plate [42] without and with glucose respectively. 
Table 3 Bacterial density at 45 DAl under gnotobiotic conditions

\begin{tabular}{llll}
\hline Treatments $^{\mathbf{1}}$ & \multicolumn{3}{l}{ Endophytic population $(\mathbf{l o g} \mathbf{~ c f u} / \mathbf{g})^{\mathbf{2}}$} \\
\cline { 2 - 4 } & Root & Stem & Leaves \\
\hline Wild type & $7.83 \pm 0.10^{\mathrm{a}}$ & $7.13 \pm 0.05^{\mathrm{a}}$ & 0 \\
nifH $\Delta$ & $7.62 \pm 0.16^{\mathrm{a}}$ & $7.02 \pm 0.19^{\mathrm{a}}$ & 0 \\
nifD $\Delta$ & $7.67 \pm 0.20^{\mathrm{a}}$ & $6.91 \pm 0.32^{\mathrm{a}}$ & 0 \\
nifK $\Delta$ & $7.65 \pm 0.14^{\mathrm{a}}$ & $6.98 \pm 0.32^{\mathrm{a}}$ & 0 \\
Mock & 0 & 0 & 0
\end{tabular}

${ }^{1} \mathrm{Wt}$ and nif mutants were labelled with pMC1-EPS-RtGFP and inoculated to root zones of 12 day-old seedlings derived from surface-sterilized. Plants were maintained in sterile conditions in sand-nutrient mix in Phytatrays.

${ }^{2}$ Number of CFU (per g dry biomass) recovered from surface-sterilized root

tissues of Jatropha curcas Cv. MD-44. Bacteria were recovered on 2xYT medium supplemented with chloramphenical $(100 \mu \mathrm{g} / \mathrm{ml})$.

${ }^{a}$ The treatments are not significantly different from each other at $5 \%$ threshold.

provided strong evidence that Enterobacter sp. R4-368 significantly improved yield parameters even in the presence of nitrogen fertilizer application and competing nitrogenfixing bacteria that are diverse and abundant in the nonsterilized soil (Figure 4; Additional file 1: Table S1). In addition, we have demonstrated that PGP activity of R4368 is only partially attributed to its nitrogen-fixing activity as $\Delta$ nif mutants retained substantial PGP activity (Table 2). Furthermore, we have showed that the nif genes of Enterobacter, from the result of partial genome sequence of Enterobacter sp. R4-368, showed the highest similarity to those of $K$. pneumoniae, which belongs to the same Enterobacteriaceae family, and have identical gene organization (Figure 5). In contrast, Enterobacter sp. 618, which is a documented efficient PGP bacterium on poplar, lacks the nif genes and, hence, growth promotion is believed to be result from secretion of auxin and volatile compounds. Although growth promotion by Enterobacter sp. 618 is also associated with increased leaf area, photosynthesis efficiency is not affected by the bacteria inoculation [42].

Colonization of Jatropha roots by strain R4-368 was very similar to that of other endophytes reported so far. Colonization events by diazotrophs have been studied in several grass species. For example, Azospirillum brasilense forms a characteristic pattern of wheat colonization that involves invasion of root hair cells [53] and colonization of the root tip [54]. Herbaspirillum seropedicae and Azoarcus sp. colonized the root cortex, root cap, epidermis, exodermis, and xylem of the host crops studied [55-57]. Pantoea agglomerans has been found in the intercellular spaces of wheat roots [58]. The colonization of maize by $K$. pneumoniae was distinct in that it was typically found in the zone of root hair formation but only occasionally formed colonies on or in the root hairs. The pattern of stem colonization contrasted with root colonization whereby the intercellular spaces of the stem cortex were inhabited by single cell or cluster of cells [59]. Enterobacter cloacae strain GS1 colonizes rice root under hydroponic conditions showed multicellular aggregates embedded in an extracellular matrix cemented to the root surface on 7 DAI [60]. We found that strain R4-368 formed microcolonies on the root hairs and also in the inter-cellular spaces of the root cortex (Figure 6A-D). When attached to roots, bacteria often increase in numbers by several cell divisions, resulting in the establishment of a microcolony. Invasion of root tissue might take place from such established microcolonies as it was able to secret endoglucanase under in vitro conditions (Figure 6G-H). Enumeration of surface-sterilized root/shoots suggests that the bacterium colonized the interior of the tissues since the experimental conditions assured complete sterilization. Another advantage of R4-368 is its ability to move stem tissue, potentially enhancing its nitrogen-fixing capacity in planta. In addition, we found that nif mutation did not significantly affect colonization of Enterobacter sp. strain R4368. This is similar to the observation with Acetobacter diazotrophicus in sugarcane [61] but it is in contrast to Azoarcus spp. in which the nif mutant lost the ability to colonize and persist in the rhizosphere of kallar grass [56]. It is interesting to note that R4-368 was not detected in leaf tissues. A direction for future research should address if synergism exists when R4-368 is coinoculated with other plant growth promoting bacteria, e.g., leaf-colonizing nitrogen-fixing strains and mycorrhiza.

\section{Conclusions}

Enterobacter sp. strain R4-368 is a very promising biofertilizer inoculant for Jatropha as it not only improved biomass accumulation but also seed yield. Mechanistically, the strains appeared to exert its growth promotion mainly by its ability to fix nitrogen in the rhizosphere and stems, thereby improving nutrient conditions of the plants, which leads to improved photosynthesis due to greater photosynthetic area and chlorophyll content. However, the strain has the other PGP activity that remains to be determined. The application of the strains is likely to significantly improve the commercial viability of Jatropha plantations due to the reduced fertilizer cost and improved oil yield.

\section{Materials and methods}

\section{Jatropha seedlings}

Seeds of J. curcas L. cv. MD44 were used throughout the experiments. Surface sterilization of seeds was done by washing coat-less seed kernels in $75 \%$ ethanol $(\mathrm{v} / \mathrm{v})$ for $1 \mathrm{~min}$ and $10 \% \mathrm{H}_{2} \mathrm{O}_{2}(\mathrm{v} / \mathrm{v})$ for $60 \mathrm{~min}$ followed by 3-5 rinses in sterilized distilled water. After soaking overnight at $28^{\circ} \mathrm{C}$ in darkness, they were germinated on a hormone-free seed germination medium (1/2 MS salt, 
B5 vitamins, $5 \mathrm{~g} \mathrm{l}^{-1}$ sucrose, $0.5 \mathrm{~g} \mathrm{l}^{-1} \mathrm{MES}$ and $2.2 \mathrm{~g} \mathrm{l}^{-1}$ phytagel, pH 5.6) in Phytatrays (Sigma, USA) in a tissue culture room with a temperature of $25^{\circ} \mathrm{C} \pm 2{ }^{\circ} \mathrm{C}$ and 16/ $8 \mathrm{~h}$ light-dark cycles.

\section{Isolation of endophytic bacteria from Jatropha cultivars}

Jatropha curcas L. accessions from Indonesia, China and India origins were sampled from the research plots of Agrotechnology Experimental Station located at Lim Chu Kang, Singapore. Root samples with adhering soil were carefully removed with a trowel paper and collected in sterile plastic bags in triplicates. After thorough washings in distilled water, samples were surfacesterilized by washing for $1 \mathrm{~min}$ in $90 \%$ ethanol and $10 \mathrm{~min}$ in $15 \% \mathrm{H}_{2} \mathrm{O}_{2}$ followed by $3-5$ rinses in sterile distilled water. Tissues were macerated separately in $10 \mathrm{ml} \mathrm{1 \times}$ PBS using a blender under sterile conditions. A $100-\mu \mathrm{l}$ sample of the water from the third rinse was plated on rich medium to verify the efficiency of sterilization. Serial dilutions were made, and 100- $\mu \mathrm{l}$ samples were spread -plated on different media [62-64] and incubated at $30^{\circ} \mathrm{C}$ for up to 7 days for the isolation of endophytes.

\section{Taxonomical analyses of isolated strains}

Genomic DNAs were prepared using the method described by Wilson [65]. PCR amplification of the $16 \mathrm{~S}$ rRNA genes was carried out with the universal primers $27 \mathrm{~F}$ and 1492R [66]. Sequencing was performed using an automated DNA sequencer model 3730 XL (AB Applied Biosystems, HITACHI). Sequence similarity was analyzed against the EzTaxon-e Database (http://eztaxon-e. ezbiocloud.net/) [67] and aligned using CLUSTAL W tool in MEGA version 5.05 [68]. Phylogenetic analyses were performed by the Neighbour-Joining [69], MaximumLikelihood [70] and Maximum-Parsimony [71] methods using the MEGA version 5.05 [69] with the bootstrap values set at 1000 replications [72].

\section{Acetylene reduction (AR) assay}

Nitrogenase activity in pure cultures was determined by growing strains in a $125 \mathrm{ml}$ serum bottle (Wheaton Industries Inc., USA) in $40 \mathrm{ml}$ nitrogen-free medium (DSMZ medium no. 3), which contains $5.0 \mathrm{~g} \mathrm{l}^{-1}$ glucose, $5.0 \mathrm{~g} \mathrm{l}^{-1}$ mannitol, $0.1 \mathrm{~g} \mathrm{l}^{-1} \mathrm{CaCl}_{2} \cdot 2 \mathrm{H}_{2} \mathrm{O}, 0.1 \mathrm{~g} \mathrm{l}^{-1} \mathrm{MgSO}_{4} \cdot 7 \mathrm{H}_{2} \mathrm{O}$, $5.0 \mathrm{mg} \mathrm{l}^{-1} \mathrm{Na}_{2} \mathrm{MoO}_{4} .2 \mathrm{H}_{2} \mathrm{O}, 0.9 \mathrm{~g} \mathrm{l}^{-1} \mathrm{~K}_{2} \mathrm{HPO}_{4}, 0.1 \mathrm{~g} \mathrm{l}^{-1}$ $\mathrm{KH}_{2} \mathrm{PO}_{4}, 0.01 \mathrm{~g} \mathrm{l}^{-1} \mathrm{FeSO}_{4} .7 \mathrm{H}_{2} \mathrm{O}, 5.0 \mathrm{~g} \mathrm{l}^{-1} \mathrm{CaCO}_{3}$ and $1 \mathrm{ml}$ trace element mixture. The trace element mixture (SL-6, in DSMZ medium no. 27) is composed of $0.1 \mathrm{~g} \mathrm{l}^{-1}$ $\mathrm{ZnSO}_{4} .7 \mathrm{H}_{2} \mathrm{O}, 0.03 \mathrm{~g} \mathrm{l}^{-1} \mathrm{MnCl}_{2} .4 \mathrm{H}_{2} \mathrm{O}, 0.3 \mathrm{~g} \mathrm{l}^{-1} \mathrm{H}_{3} \mathrm{BO}_{3}$, $0.2 \mathrm{~g} \mathrm{l}^{-1} \mathrm{CoCl}_{2} \cdot 6 \mathrm{H}_{2} \mathrm{O}, 0.01 \mathrm{~g} \mathrm{l}^{-1} \mathrm{CuCl}_{2} \cdot 2 \mathrm{H}_{2} \mathrm{O}$ and $0.02 \mathrm{~g} \mathrm{l}^{-1}$ $\mathrm{NiCl}_{2} \cdot 6 \mathrm{H}_{2} \mathrm{O}$ in water [73]. Acetylene reduction assay was performed by injecting purified acetylene into the bottles sealed with gas-tight serum stoppers to yield 15\% acetylene $(\mathrm{v} / \mathrm{v})$; this was followed by incubation for up to $96 \mathrm{~h}$ at $30^{\circ} \mathrm{C}$. To determine the in planta nitrogenase activity, AR assay was performed with plants inoculated with isolated strains at 30 and 45 DAI. Root samples were separated from seedlings after carefully removing the adhered soil; placed in $250 \mathrm{ml}$ glass bottles and sealed with a rubber septum. After removing an equivalent volume of air, acetylene was injected into these bottles to give a final concentration of $10 \%$ and incubated at $30^{\circ} \mathrm{C}$ for $24 \mathrm{~h}$. Gas samples $(0.5 \mathrm{ml}$ for pure cultures and $0.8 \mathrm{ml}$ for plants) were removed at regular intervals with a PTFEsyringe (Hewlett-Packard, USA) and analyzed in a GCMS-QP2010 Ultra Gas Chromatograph (Shimadzu Corporation, Japan) with an flame ionization detector and GS-Alumina (30 $\mathrm{m} \times 0.53 \mathrm{~mm}$ I.D.) column and operated under the following conditions: carrier gas: $\mathrm{He}-30 \mathrm{ml} / \mathrm{min}$; detector temperature: $200^{\circ} \mathrm{C}$; pressure: 4.0 psi. Ethylene produced by the bacteria was quantified using standard ethylene $\left(\mathrm{C}_{2} \mathrm{H}_{4}\right.$, Product Number: 00489, Sigma-Aldrich) curve prepared in duplicates in concentrations ranging from 1-1000 nmol. All values expressed were obtained after deducting the ethylene values for a blank treatment without samples. For in planta AR activity, the values were subtracted against a basal ethylene level which is released by plant tissues, i.e., value of a control with no injected acetylene gas. The protein concentration was determined by a modified Lowry method with bovine serum albumin as standard.

\section{Molecular techniques and DNA manipulations}

DNA isolations, transformations, electrophoration, restriction enzyme digestions, electrophoresis, ligations and hybridizations were performed using standard procedures $[65,74]$. Electrophoration was carried out with a Micropulser $^{\text {TM }}$ (Bio-Rad, Hercules, CA) set at $2.5 \mathrm{kV}$ $\left(12.5 \mathrm{kV} \mathrm{cm}^{-1}\right) ; 25 \mu \mathrm{F} ; 200 \Omega$ and Gene Pulser ${ }^{\circledR}$ Cuvettes (0.1 cm electrode gap). Enterobacter sp. R4-368 was made electrocompetent after overnight growth in $2 \mathrm{xYT}$ broth medium at $30^{\circ} \mathrm{C}$ with shaking $(200 \mathrm{rpm})$. One milliliter of the overnight culture was used to inoculate $500 \mathrm{ml}$ of $2 \mathrm{xYT}$ and incubated aerobically at $30^{\circ} \mathrm{C}$, with shaking until it reached an $A_{600}$ of 0.6 to 0.75 , at which point the culture was chilled on ice for $15 \mathrm{~min}$. Bacterial cells were pelleted at $8,000 \mathrm{rpm}$ for $10 \mathrm{~min}$, washed 2 times, first in $75 \mathrm{ml}$ of ice-cold $10 \%$ glycerol and then in $50 \mathrm{ml}$ of ice-cold $10 \%$ glycerol, and resuspended in $1 \mathrm{ml}$ of ice-cold $10 \%$ glycerol. The resultant electrocompetent cells had a transformation efficiency of $10^{7}$ to $10^{9} \mathrm{CFU} / \mu \mathrm{g}$ of DNA.

For construction of deletion mutant of nif genes, approximately $1 \mathrm{~kb}$ fragment of the upstream and downstream flanking sequences of the respective gene were amplified by PCR using primers containing appropriate 
recognition sites for restriction enzymes (Additional file 3: Figure S2). The sequences and details of the primers are mentioned in Additional file 4: Table S2. The amplified PCR fragments were cloned sequentially into the pSTn5-KM (Genbank accession no. KC989926). After DNA sequence verification, deletion cassettes were amplified using primers P1 and P4 (Additional file 4: Table S2); purified with PCR Clean kit (Qiagen, USA) and concentrated by ethanol precipitation. The purified DNA was transformed to Enterobacter sp. R4-368 by electroporation. The transformants were confirmed by locus-specific PCR using specific primer targeting a region immediately upstream of downstream of the homology region and a primer targeting the STn 5 region. Candidate knockout strains were confirmed by Southern blotting, which was conducted by blotting $1 \mu \mathrm{g}$ of restriction enzyme-digested genomic DNA onto Hybond $\mathrm{N}^{+}$membranes (GE Healthcare, USA). The blot was hybridized against Dig-labelled DNA probe using DIG High Prime DNA labelling and the targeted DNA was detected according to the Dig starter kit according to the instruction of the manufacturer (Roche Applied Science, Germany). GFP tagging of wild-type and $\Delta$ nif mutants of Enterobacter sp. R4-368 was done by electroporation of pMC1-EPS-RtGFP to the competent cells (Genbank accession no. KC989925). Transformants were selected on ABM agar medium with $100 \mu \mathrm{g} \mathrm{ml}^{-1}$ chloramphenicol.

\section{Bacterial inoculation of Jatropha}

Enterobacter strains were cultured in $2 \mathrm{xYT}$ broth to until exponential growth phase and harvested by centrifugation. After washing once with water, inoculants were made by re-suspending the pellets in water to an $\mathrm{OD}_{600 \mathrm{~nm}}$ of $1.2\left(\sim 10^{8} \mathrm{cfu}\right.$ per $\left.\mathrm{ml}\right)$. Depending on the experiments, inoculation was done either by seed soaking or watering to the soil. For gnotobiotic assay for root colonization, seedlings were transferred to phytatrays containing $200 \mathrm{~g}$ of sterilized sand filled with $40 \mathrm{ml}$ of plant nutrient solution [35]. The phytatrays were covered with lid, and incubated in a growth chamber with a temperature of $28^{\circ} \mathrm{C}$ and $16 / 8 \mathrm{~h}$ day-night cycles. Bacterial inoculants $(5 \mathrm{ml} /$ tray $)$ were diluted into nutrient solution and applied to sand near root zone.

For assessing the impact on seed germination and early growth of the seedlings, seeds were sown in germination trays filled with the pot mixture and inoculated with $2 \mathrm{ml}$ of the inoculants. Root application was done after germination and the growth parameters were observed at 45 DAS. For pot cultivation experiments under $\mathrm{N}$-limiting conditions, healthy seedlings derived from surface-sterilized seeds were transferred to pots containing a mixture of perlite, vermiculite and sand in 1:1:1 ratio $(\mathrm{v} / \mathrm{v})$. Bacterial inoculants $(50 \mathrm{ml} / \mathrm{pot})$ were applied to the soil around the stems or disturb the top soil before application of inoculants for wetting the root zone. Plants were grown under glasshouse conditions. Plants were watered as needed with a plant nutrient solution containing with $2 \mathrm{mM} \mathrm{N}$ or without $\mathrm{N}$-source.

To assess the effects of bacterial inoculation on the growth and yield of Jatropha under natural conditions, two pot culture experiments were conducted with garden soil. Healthy seedlings were transferred from germination trays to the pots and bacterial inoculant (50 ml/pot) were applied near the root zone. Commercial NPK fertilizer was applied about once every 15 days. Biometric observations were recorded once in 30 days. After flowering, yield parameters were recorded once in 30 days.

\section{Quantification of nitrogen content and leaf chlorophyll}

Leaf chlorophyll concentrations were measured using the at LEAF chlorophyll meter (FT Green LLC, Wilmington, USA). Relative chlorophyll concentration is the ratio of transmittance between red $(650 \mathrm{~nm})$ and infrared $(940 \mathrm{~nm})$ emissions through the leaf. Leaf nitrogen $(\mathrm{N})$ content was determined by the combustion method in an elemental analyzer (Vario EL Elemental Analyzer, Elementar, Germany) equipped with a thermal conductivity detector on an Elementar Vario Micro Cube. Accurately-weighed 5-mg ground dried leaf samples were placed in tin capsules for combustion at $1,150^{\circ} \mathrm{C}$ in the elemental analyzer reactor.

\section{Confocal laser scanning microscopy (CLSM)}

Transverse sections of surface sterilized tissues were cut manually and observed under a CLSM ( $\mathrm{Zl}$ with motorized stage; Carl Zeiss Inc., Jena $\mathrm{GmbH}$, Germany) equipped with a krypton and an argon laser and supported by the Laser Scanning System LSM5 PASCAL software (Carl Zeiss Inc.). Stacks were obtained using a Microscope Zeiss Axio Imager and the data was analyzed with Zeiss LSM Image Browser version 4.0 program (Carl Zeiss Inc.). Bacterial colonization of Jatropha roots was analyzed from 3-D confocal data stacks.

\section{Statistical analysis}

Bacterial population data were log transformed before being subjected to further analysis. The data were subjected to analysis of variance and testing of means by Duncan's Multiple Range Test (DMRT) at $P \leq 0.05$ using SAS package, Version 9.2 (SAS Institute Inc., Cary, NC, USA). Student's t-test was done using the JavaScript maintained by Professor Hossein Arsham, Johns Hopkins Carey Business School, (http://home.ubalt.edu/ntsbarsh/Business-stat/otherapplets/ MeanTest.htm). 


\section{Additional files}

Additional file 1: Table S1. Effects of R4-368 inoculation on flower sex ratio and seed yield parameters of Jatropha.

Additional file 2: Figure S1. Molecular construction and characterization of $\Delta$ nif mutants. (A) Acetylene reduction activity compared with strain R4-368 and their nif mutants, (B) DNA blot analysis. Genomic DNA (gDNA) was isolated from $\Delta$ nifH, $\Delta$ nifD and $\Delta$ nifK knockout mutants. Genomic DNA aliquots $(1 \mu \mathrm{g})$ were digested with individual restriction enzymes and subjected to agarose gel electrophoresis. The DNA blot was hybridized with a DIG-labeled nifH, nifD and nifK-flanking region as DNA probe. WT-wild type strain R4-368; M- DNA Molecular Weight Marker III (Roche Applied Science, Germany).

Additional file 3: Figure S2. Map showing $\Delta$ nifH (A), $\Delta$ nifD (B) and $\Delta$ nifk (C) knock out constructs.

Additional file 4: Table S2. List of primers used in this study.

\section{Abbreviations}

ARA: Acetylene reduction activity; CDS: Coding DNA sequence; CFU: Colony forming units; CLSM: Confocal laser scanning microscopy; DAl: Days after inoculation; DMRT: Duncan's multiple range test; PGP: plant growth promotion; RAST: Rapid annotation using subsystem technology; RG: Rate of germination; SVI: Seedling vigour index.

\section{Competing interests}

The authors declare that they have no competing interests.

\section{Authors' contributions}

MM, JL and HY conceived experiments and drafted the manuscript. MM performed strain isolation and characterization and bioassays for bacteria and plants. PN and $\mathrm{CHI}$ prepared DNA constructs for gene knockout and GFP tagging. NST participated in the PGP traits experiments and data analysis. CL, FL, CR participated in the bioassay for plants. All the authors have read and approved the final manuscript.

\section{Authors' information}

$J$ is Head of the laboratory and a Director of the Institute's Strategic Research Program. MM is a postdoctoral fellow, PN is PhD student, CL is senior Research Officer, and FL, CHI and NST are Assistant Research Officer at the Temasek Life Sciences Laboratory, 1 Research Link, NUS, Singapore 117604. HY is Chief Scientific Officer and CR is Manager (Agronomist), Joil Pte Ltd, 1 Research Link, National University of Singapore, Singapore 117604.

\section{Acknowledgements}

This work was supported by the Temasek Foundation and the Singapore Economy Development Board (EDB). We also thank Dr. Meredith Calvert and Ms. Fiona Chia (Microscopy and Imaging Facility, TLL, Singapore) for their assistance with confocal laser scanning microscopy.

\section{Author details}

${ }^{1}$ Biomaterials and Biocatalysts Group, Temasek Life Sciences Laboratory, 1 Research Link, National University of Singapore, Singapore 117604, Republic of Singapore. ${ }^{2}$ Joil Pte Ltd, 1 Research Link National University of Singapore, Singapore 117604, Republic of Singapore.

Received: 17 May 2013 Accepted: 26 September 2013 Published: 1 October 2013

\section{References}

1. Chang MCY: Harnessing energy from plant biomass. Curr Opin Chem Biol 2007, 11:677-684.

2. Barton PK, Atwater JW: Nitrous oxide emissions and the anthropogenic nitrogen in wastewater and solid waste. J Environ Eng 2002, 128:137-150.

3. Galloway JN, Townsend AR, Erisman JW, Bekunda M, Cai Z, Freney JR, Martinelli LA, Seitzinger SP, Sutton MA: Transformation of the nitrogen cycle: recent trends, questions, and potential solutions. Science 2008, 320:889-892.

4. Melillo JM, Reilly JM, Kicklighter DW, Gurgel AC, Cronin TW, Paltsev S, Felzer BS, Wang $X$, Sokolov AP, Schlosser CA: Indirect emissions from biofuels: How important? Science 2009, 326:1397-1399.
5. Crutzen PJ, Mosier AR, Smith KA, Winiwarter $W: \mathrm{N}_{2} \mathrm{O}$ release from agrobiofuel production negates global warming reduction by replacing fossil fuels. Atmos Chem Phys 2008, 8:389-395.

6. Fairless D: Biofuel: the little shrub that could - maybe. Nature 2007 449:652-655.

7. Gaydou AM, Menet L, Ravelojaona G, Geneste P: Vegetable energy sources in Madagascar: ethyl alcohol and oil seeds. Oleagineux 1982, 37:135-141.

8. Openshaw K: A review of Jatropha curcas: an oil plant of unfulfilled promise. Biomass Bioenerg 2000, 19:1-15.

9. Behera SK, Srivastava P, Tripathi R, Singh J, Singh N: Evaluation of plant performance of jatropha curcas L. Under different agro-practices for optimizing biomass-a case study. Biomass Bioenerg 2010, 34:30-41.

10. Liu P, Wang CM, Li L, Sun F, Yue GH: Mapping QTLs for oil traits and eQTLs for oleosin genes in jatropha. BMC Plant Biol 2011, 11:132.

11. Sun F, Liu P, Ye J, Lo LC, Cao S, Li L, Yue GH, Wang CM: An approach for jatropha improvement using pleiotropic QTLs regulating plant growth and seed yield. Biotechnol Biofuels 2012, 5:1-10.

12. Yong J, Ng Y, Tan S, Chew A: Effect of fertilizer application on photosynthesis and oil yield of Jatropha curcas L. Photosynthetica 2010, 48:208-218.

13. Ghosh A, Chikara J, Chaudhary D, Prakash AR, Boricha G, Zala A: Paclobutrazol arrests vegetative growth and unveils unexpressed yield potential of Jatropha curcas. J Plant Growth Regul 2010, 29:307-315.

14. Pan B-Z, Xu Z-F: Benzyladenine treatment significantly increases the seed yield of the biofuel plant Jatropha curcas. J Plant Growth Regul 2011, 30:166-174.

15. Jourand P, Giraud E, Bena G, Sy A, Willems A, Gillis M, Dreyfus B, De-Lajudie $P$ : Methylobacterium nodulans sp. nov., for a group of aerobic, facultatively methylotrophic, legume root-nodule-forming and nitrogenfixing bacteria. Int J Syst Evol Microbiol 2004, 54:2269-2273.

16. Kaneko T, Nakamura Y, Sato S, Asamizu E, Kato T, Sasamoto S, Watanabe A, Idesawa K, Ishikawa A, Kawashima K: Complete genome structure of the nitrogen-fixing symbiotic bacterium Mesorhizobium loti. DNA Res 2000, 7:331-338.

17. Stacey G, So JS, Roth LE, Lakshmi SKB, Carlson RW: A lipopolysaccharide mutant of Bradyrhizobium japonicum that uncouples plant from bacterial differentiation. Mol Plant Microbe Interact 1991, 4:332-340.

18. Gottfert M, Rothlisberger S, Kundig C, Beck C, Marty R, Hennecke H: Potential symbiosis-specific genes uncovered by sequencing a 410 kilobase DNA region of the Bradyrhizobium japonicum chromosome. J Bacteriol 2001, 183:1405.

19. Long SR: Rhizobium symbiosis: nod factors in perspective. Plant Cell 1885, 1996:8.

20. Young J, Johnston A: The evolution of specificity in the legumeRhizobium symbiosis. Trends Ecol Evol 1989, 4:341-349.

21. Moir JW: Nitrogen cycling in bacteria: molecular analysis. Caister Academic Press; 2011. http://www.horizonpress.com/nitrogen-cycle.

22. Peters NK, Frost JW, Long SR: A plant flavone, luteolin, induces expression of Rhizobium meliloti nodulation genes. Science 1986, 233:977.

23. Maxwell CA, Hartwig UA, Joseph CM, Phillips DA: A chalcone and two related flavonoids released from alfalfa roots induce nod genes of Rhizobium meliloti. Plant Physiol 1989, 91:842.

24. Antoun H, Beauchamp CJ, Goussard N, Chabot R, Lalande R: Potential of rhizobium and bradyrhizobium species as plant growth promoting rhizobacteria on non-legumes: effect on radishes (Raphanus sativus L.). Plant Soil 1998, 204:57-67.

25. Zehr JP: Nitrogen fixation by marine cyanobacteria. Trends Microbio/ 2011, 19:162-173.

26. Rediers H, Vanderleyden J, De-Mot R: Azotobacter vinelandii: a Pseudomonas in disguise? Microbiology 2004, 150:1117-1119.

27. Pedraza RO: Recent advances in nitrogen-fixing acetic acid bacteria. Int $J$ Food Microbiol 2008, 125:25-35.

28. Liu $Y$, Wang $H$, Sun $X$, Yang $H$, Wang $Y$, Song W: Study on mechanisms of colonization of nitrogen-fixing PGPB, Klebsiella pneumoniae NG14 on the root surface of rice and the formation of biofilm. Curr Microbiol 2011, 62:1113-1122.

29. Boddey R, Oliveira OC, Urquiaga S, Reis V, Olivares FL, Baldani V, Döbereiner J: Biological nitrogen fixation associated with sugar cane and rice: contributions and prospects for improvement. Plant Soil 1995, 174:195-209.

30. Baldani Jl, Reis VM, Baldani VLD, Döbereiner J: Review: a brief story of nitrogen fixation in sugarcane- reasons for success in brazil. Funct Plant Biol 2002, 29:417-423. 
31. Lin L, Li Z, Hu C, Zhang X, Chang S, Yang L, Li Y, An Q: Plant growthpromoting nitrogen-fixing Enterobacteria are in association with sugarcane plants growing in Guangxi, China. Microbes Environ 2012, 27:391-398.

32. Saravanan VS, Madhaiyan M, Osborne J, Thangaraju M, Sa TM: Ecological occurrence of gluconacetobacter diazotrophicus and nitrogen-fixing acetobacteraceae members: their possible role in plant growth promotion. Microb Ecol 2008, 55:130-140.

33. Senthilkumar M, Madhaiyan M, Sundaram S, Kannaiyan S: Intercellular colonization and growth promoting effects of Methylobacterium sp. with plant-growth regulators on rice (Oryza sativa L. Cv CO-43). Microbiol Res 2009, 164:92-104

34. Madhaiyan M, Poonguzhali S, Senthilkumar M, Seshadri S, Chung H, Jinchul Y, Sundaram S, Tongmin S: Growth promotion and induction of systemic resistance in rice cultivar Co-47 (Oryza sativa L.) by Methylobacterium spp. Bot Bull Acad Sin 2004, 45:315-324.

35. Iniguez AL, Dong Y, Triplett EW: Nitrogen fixation in wheat provided by Klebsiella pneumoniae 342. Mol Plant Microbe Int 2004, 17:1078-1085.

36. Abdul-Baki AA, Anderson JD: Vigor determination in soybean seed by multiple criteria. Crop Sci 1973, 13:630-633.

37. Roberts GP, MacNeil T, MacNeil D, Brill WJ: Regulation and characterization of protein products coded by the nif (nitrogen fixation) genes of Klebsiella pneumoniae. J Bacteriol 1978, 136:267-279.

38. Arnold W, Rump A, Klipp W, Priefer UB, Pühler A: Nucleotide sequence of a 24,206-base-pair DNA fragment carrying the entire nitrogen fixation gene cluster of Klebsiella pneumoniae. J Mol Biol 1988, 203:715-738.

39. Aziz RK, Bartels D, Best AA, DeJongh M, Disz T, Edwards RA, Formsma K, Gerdes S, Glass EM, Kubal M: The RAST Server: rapid annotations using subsystems technology. BMC Genomics 2008, 9:75.

40. De-Lorenzo V, Herrero M, Jakubzik U, Timmis KN: Mini-Tn5 transposon derivatives for insertion mutagenesis, promoter probing, and chromosomal insertion of cloned DNA in gram-negative eubacteria. J Bacteriol 1990, 172:6568-6572.

41. Liu Y, Koh C, Sun L, Hlaing M, Du M, Peng N, Ji L: Characterization of glyceraldehyde-3-phosphate dehydrogenase gene RtGPD1 and development of genetic transformation method by dominant selection in oleaginous yeast Rhodosporidium toruloides. Appl Microbiol Biotechnol 2013, 97:719-729.

42. Compant S, Reiter B, Sessitsch A, Nowak J, Clément C, Barka EA: Endophytic colonization of Vitis vinifera L. by plant growth-promoting bacterium Burkholderia sp. strain PsJN. Appl Environ Microbiol 2005, 71:1685-1693.

43. Long HH, Schmidt DD, Baldwin IT: Native bacterial endophytes promote host growth in a species-specific manner; phytohormone manipulations do not result in common growth responses. PLoS One 2008, 3:e2702.

44. Qin S, Xing K, Fei S-M, Lin Q, Chen X-M, Cao C-L, Sun Y, Wang Y, Li W-J, Jiang J-H: Pseudonocardia sichuanensis sp. nov., a novel endophytic actinomycete isolated from the root of Jatropha curcas L. Anton Leeuw Int J G 2011, 99:395-401.

45. Xing K, Qin S, Fei S-M, Lin Q, Bian G-K, Miao Q, Wang Y, Cao C-L, Tang S-K, Jiang J-H: Nocardia endophytica sp. nov., an endophytic actinomycete isolated from the oil-seed plant Jatropha curcas L. Int I Syst Evol Microbiol 2011, 61:1854-1858.

46. Madhaiyan M, Jin TY, Roy JJ, Kim S-J, Weon H-Y, Kwon S-W, Ji L: Pleomorphomonas diazotrophica sp. nov., a novel endophytic $\mathrm{N}$-fixing bacterium isolated from the root tissue of Jatropha curcas L. Int J Syst Evol Microbiol 2013, 63:2477-2483.

47. Madhaiyan M, Hu CJ, Roy JJ, Kim S-J, Weon H-Y, Kwon S-W, Ji L: Aureimonas jatrophae sp. nov. and Aureimonas phyllosphaerae sp. nov., two novel leaf-associated bacteria isolated from Jatropha curcas L. Int I Syst Evol Microbiol 2013, 63:1702-1708.

48. Madhaiyan M, Hu CJ, Kim S-J, Weon H-Y, Kwon S-W, Ji L: Jatrophihabitans endophyticus gen. nov., sp. nov., a novel endophytic actinobacteria isolated from a surface-sterilized stem of Jatropha curcas L. Int I Syst Evol Microbiol 2013, 63:1241-1248

49. Jha CK, Patel B, Saraf M: Stimulation of the growth of Jatropha curcas by the plant growth promoting bacterium Enterobacter cancerogenus MSA2. World J Microbiol Biotechnol 2012, 28:891-899.

50. Kämpfer $\mathrm{P}$, Ruppel S, Remus R: Enterobacter radicincitans sp. nov., a plant growth promoting species of the family Enterobacteriaceae. Syst Appl Microbiol 2005, 28:213-221.

51. Remus R, Ruppel S, Jacob HJ, Hecht-Buchholz C, Merbach W: Colonization behaviour of two enterobacterial strains on cereals. Biol Fertil Soils 2000, 30:550-557.
52. Ruppel S, Rühlmann J, Merbach W: Quantification and localization of bacteria in plant tissues using quantitative real-time PCR and online emission fingerprinting. Plant Soil 2006, 286:21-35.

53. Assmus B, Hutzler P, Kirchhof G, Amann R, Lawrence JR, Hartmann A: In situ localization of Azospirillum brasilense in the rhizosphere of wheat with fluorescently labeled, rRNA-targeted oligonucleotide probes and scanning confocal laser microscopy. Appl Environ Microbiol 1995, 61:1013-1019.

54. Schloter M, Hartmann A: Endophytic and surface colonization of wheat roots (Triticum aestivum) by different Azospirillum brasilense strains studied with strain-specific monoclonal antibodies. Symbiosis 1998, 25:159-179.

55. James EK, Olivares FL: Infection and colonization of sugar cane and other graminaceous plants by endophytic diazotrophs. Crit Rev Plant Sci 1998, 17:77-119.

56. Hurek T, Reinhold-Hurek B, Van-Montagu M, Kellenberger E: Root colonization and systemic spreading of Azoarcus sp. strain BH72 in grasses. J Bacteriol 1994, 176:1913-1923.

57. Reinhold-Hurek B, Hurek T: Life in grasses: diazotrophic endophytes. Trends Microbiol 1998, 6:139-144.

58. Ruppel S, Hecht-Buchholz C, Remus R, Ortmann U, Schmelzer R: Settlement of the diazotrophic, phytoeffective bacterial strain Pantoea agglomerans on and within winter wheat: an investigation using ELISA and transmission electron microscopy. Plant Soil 1992, 145:261-273.

59. Chelius MK, Triplett EW: Immunolocalization of dinitrogenase reductase produced by Klebsiella pneumoniae in association with Zea mays L. Appl Environ Microbiol 2000, 66:783-787.

60. Shankar M, Ponraj P, llakkiam D, Gunasekaran P: Root colonization of a rice growth promoting strain of Enterobacter cloacae. J Basic Microbiol 2011, 51:523-530.

61. Sevilla M, Burris RH, Gunapala N, Kennedy C: Comparison of benefit to sugarcane plant growth and ${ }^{15} \mathrm{~N}_{2}$ incorporation following inoculation of sterile plants with Acetobacter diazotrophicus wild-type and nif mutant strains. Mol Plant Microbe Interact 2001, 14:358-366.

62. Baldani VLD, Döbereiner J: Host-plant specificity in the infection of cereals with Azospirillum spp. Soil Biol Biochem 1980, 12:433-439.

63. Barac T, Taghavi S, Borremans B, Provoost A, Oeyen L, Colpaert JV, Vangronsveld J, van der-Lelie D: Engineered endophytic bacteria improve phytoremediation of water-soluble, volatile, organic pollutants. Nature Biotechnol 2004, 22:583-588.

64. Whittenbury R, Phillips $\mathrm{K}$, Wilkinson J: Enrichment, isolation and some properties of methane-utilizing bacteria. J Gen Microbiol 1970, 61:205-218.

65. Wilson K: Preparation of genomic DNA from bacteria. Curr Prot Mol Biol 2001, 2.4:1-2. 4. 5 .

66. DeLong EF: Archaea in coastal marine environments. Proc Natl Acad Sci U S A 1992, 89:5685-5689.

67. Kim OS, Cho YJ, Lee K, Yoon SH, Kim M, Na H, Park SC, Jeon YS, Lee JH, Yi $\mathrm{H}$ : Introducing EzTaxon-e: a prokaryotic 16S rRNA gene sequence database with phylotypes that represent uncultured species. Int I Syst Evol Microbiol 2012, 62:716-721.

68. Tamura K, Peterson D, Peterson N, Stecher G, Nei M, Kumar S: MEGA5: molecular evolutionary genetics analysis using maximum likelihood, evolutionary distance, and maximum parsimony methods. Mol Biol Evol 2011, 28:2731-2739.

69. Saitou N, Nei M: The neighbor-joining method: a new method for reconstructing phylogenetic trees. Mol Biol Evol 1987, 4:406-425.

70. Felsenstein J: Evolutionary trees from DNA sequences: a maximum likelihood approach. J Mol Evol 1981, 17:368-376.

71. Fitch WM: Toward defining the course of evolution: minimum change for a specific tree topology. Syst Biol 1971, 20:406-416.

72. Felsenstein J: Confidence limits on phylogenies: an approach using the bootstrap. Evolution 1985, 39:783-791.

73. Im W-T, Kim S-H, Kim MK, Ten LN, Lee S-T: Pleomorphomonas koreensis sp. nov., a nitrogen-fixing species in the order Rhizobiales. Int I Syst Evol Microbiol 2006, 56:1663-1666.

74. Sambrook J, Russell DW: Molecular cloning: a laboratory manual. CSHL press; 2001

doi:10.1186/1754-6834-6-140

Cite this article as: Madhaiyan et al.: Improvement of plant growth and seed yield in Jatropha curcas by a novel nitrogen-fixing root associated Enterobacter species. Biotechnology for Biofuels 2013 6:140. 